\title{
Effect of Antioxidant Agents on Bond Strength of Composite to Bleached Enamel with $38 \%$ Hydrogen Peroxide
}

\author{
Juliane Marcela Guimaraes da Silva, Ana Carolina Botta*, Daphne Câmara Barcellos, \\ Clovis Pagani, Carlos Rocha Gomes Torres \\ São Paulo State University - UNESP, São José dos Campos School of Dentistry, \\ São José dos Campos, SP, Brazil
}

Received: January 21, 2011; Revised: April 18, 2011

\begin{abstract}
This study evaluated the effect of antioxidant agents on microtensile bond strengths ( $\mu$ TBS) of composite to bleached enamel. Fifteen freshly extracted human third molars were selected and randomly assigned to 6 groups ( $\mathrm{n}=5$ ): (NB) enamel not bleached, (B) bleached enamel, (BR7) bleached enamel and restored 7 days later, (BSA) bleached enamel+sodium ascorbate, (BMC) bleached enamel+malvidin chloride, (BPC) bleached enamel+pelargonidin chloride. The groups were bleached with $38 \%$ hydrogen peroxide (HP - Opalescence Xtra Boost) and restored with Single Bond+Filtek Z350. The specimens were thermocycled and submitted to a microtensile load at $1 \mathrm{~mm} / \mathrm{min}$ crosshead speed. The data were evaluated by ANOVA and Tukey test at $5 \%$ of significance. The mean and standard-deviation for all groups were: NB: 30.95( \pm 11.97$) a$; BSA: $30.34( \pm 8.73)$ a, BPC: $22.81(6.00) b$, BR7: 21.41( \pm 6.12$)$ b, B: $14.10( \pm 4.45)$ c, BMC: $13.25( \pm 6.02)$ c. Sodium ascorbate reversed the bond strengths to enamel immediately after bleaching.
\end{abstract}

Keywords: dental bleaching, antioxidant agents, enamel, microtensile bond strength

\section{Introduction}

The bond strength of adhesive restorations to teeth structures is reduced after bleaching procedures ${ }^{1,2}$, due to the presence of residual peroxide, which interferes with the resin polymerization ${ }^{3}$. A restorative procedure is impossible to perform immediately after bleaching, due to the decrease in bond strength of composite to bleached enamel.

The recommended post bleaching waiting period for bonding procedures varies from 24 hours to 4 weeks ${ }^{1,4,5}$. This period is important for stabilization of dental color in order to obtain better aesthetics results while the selection of the color of composite resin to be used. However, this waiting period makes it impossible to perform restorative procedures immediately after the bleaching. Thus, further research is necessary to identify possible techniques that may reduce this post bleaching waiting period.

Several methods have been proposed to reverse the compromised bond strength after bleaching, such as removal of superficial layer of enamel ${ }^{6}$, treatment of the bleached enamel with alcohol before the restoration ${ }^{7}$, use of adhesives containing organic solvents ${ }^{8,9}$, and application of antioxidant agents $\mathrm{s}^{2,5,10,11}$.

Various enzymatic agents such as, catalase ${ }^{1}$ and peroxidase; and non-enzymatic agents such as, sodium ascorbate ${ }^{1,2,5,12}$, flavonoids ${ }^{13}$ and vitamin $\mathrm{E}^{14}$ have been found to have antioxidant properties. Sodium ascorbate is water soluble and can eliminate free radicals in biological systems and prevent the acidic effect ${ }^{1,15}$. The flavonoids containing the highest antioxidant properties are anthocyanins (cyanidin, malvidin, and pelargonidin) ${ }^{13}$, which are present in fruits and vegetables. However, there is no study in the literature describing the effect of these non-enzymatic agents on the bond strength of adhesive restorations to bleached enamel.
Thus, the aim of this study was to evaluate the effect of different antioxidant agents on the microtensile bond strengths of composite restorations to enamel bleached with $38 \%$ hydrogen peroxide. The null hypothesis was that the bond strength of the composite restorations to enamel bleached with $38 \%$ hydrogen peroxide was not affected by the application of different antioxidant agents.

\section{Material and Methods}

\subsection{Tooth preparation}

Fifteen freshly extracted human third molars were used in this study after Ethic Research Committee approval from São José dos Campos School of Dentistry, São Paulo State University (UNESP), Brazil.

All teeth were cleaned with a rubber cup and pumice, stored in $1 \%$ chloramine $\mathrm{T}$ solution at $4{ }^{\circ} \mathrm{C}$ for 7 days and distilled water at $-18^{\circ} \mathrm{C}$ until use.

The teeth were sectioned $2.0 \mathrm{~mm}$ below of cemento-enamel junction with a precision low-speed diamond saw (KG Sorensen/ Rio de Janeiro, RJ, Brazil). Two rectangular enamel specimens of $8.0 \times 4.0 \times 3 \mathrm{~mm}^{3}$ from the middle third of mesial and distal surface of each tooth were obtained.

The specimens were randomly assigned into six experimental groups $(n=5)$ according to: bleaching (present or absent); antioxidant agents used (sodium ascorbate, malvidin chloride, pelargonidin chloride); and restorative procedures (immediate or 7 days later) as described in Table 1. 
Table 1. Experimental groups.

\begin{tabular}{cl}
\hline Groups & \multicolumn{1}{c}{ Description } \\
\hline NB & $\begin{array}{l}\text { No bleaching }+7 \text { days delay for restorative } \\
\text { procedures (control) }\end{array}$ \\
B & $\begin{array}{l}\text { Bleaching + immediate restorative procedures } \\
\text { Bleaching + 7 days delay for restorative procedures }\end{array}$ \\
BR7 & $\begin{array}{l}\text { Bleaching + sodium ascorbate }+ \text { immediate } \\
\text { restorative procedures }\end{array}$ \\
BSA & $\begin{array}{l}\text { Bleaching + malvidin chloride }+ \text { immediate } \\
\text { restorative procedures }\end{array}$ \\
BMC & $\begin{array}{l}\text { Bleaching + pelargonidin chloride }+ \text { immediate } \\
\text { restorative procedures }\end{array}$ \\
\hline
\end{tabular}

\subsection{Artificial saliva immersion}

All groups were immersed in $250 \mathrm{~mL}$ of artificial saliva solution at $37^{\circ} \mathrm{C}$ for 7 days, which was changed twice daily during this period. After that, the specimens were washed with an air/water syringe for 30 seconds.

The artificial saliva solution (Byoformula, São José dos Campos, SP, Brazil) consisted of $1 \mathrm{~g}$ sodium carboxymethylcellulose, $4.3 \mathrm{~g}$ xylitol, $0.1 \mathrm{~g}$ potassium chloride, $5 \mathrm{mg}$ calcium chloride, $40 \mathrm{mg}$ potassium phosphate, $1 \mathrm{mg}$ potassium thiocyanate and $100 \mathrm{~g}$ distilled deionized water at $\mathrm{pH} 7$.

\subsection{Bleaching procedures}

The specimens of B, BR7, BSA, BMC and BPC groups were bleached with $38 \%$ hydrogen peroxide (Opalescence Xtra Boost, Ultradent Products Inc., South Jordan, Utah, USA) with three applications of 15 minutes each, without light activation following the manufacturer's instructions. The bleaching gel was mixed each 5 minutes using a microbrush. After each application, the specimens were washed with an air/water spray for thirty seconds and blot-dried. All specimens were rinsed with distilled water for 1 minute $^{15}$ after the bleaching procedures.

The BR7 group was immersed in artificial saliva at $37{ }^{\circ} \mathrm{C}$ for 7 days after bleaching.

\subsection{Application of antioxidant agents}

Three different antioxidant agents (sodium ascorbate, malvidin chloride, and pelargonidin chloride) were applied to the specimens of BSA, BMC and BPC groups immediately after the bleaching procedure.

The 1-ascorbic acid sodium salt $\left(\mathrm{C}_{6} \mathrm{H}_{7} \mathrm{NaO}_{6}\right.$, Sigma-Aldrich Brazil Ltda., São Paulo, SP, Brazil) in crystalline form and molecular weight of 198.11 was used to produce the $10 \%$ sodium ascorbate solution. The malvidin chloride solution was prepared with $200 \mu \mathrm{g}$ malvidin chloride $\left(\mathrm{C}_{17} \mathrm{H}_{15} \mathrm{ClO}_{7}\right.$, molecular weight of 366.75, Sigma-Aldrich Brazil Ltda., São Paulo, SP, Brazil) per ml distilled water ${ }^{16}$. The same proportion was used with pelargonidin chloride $\left(\mathrm{C}_{15} \mathrm{H}_{11} \mathrm{ClO}_{5}\right.$, molecular weight of 306.70, Sigma-Aldrich Brazil Ltda., São Paulo, SP, Brazil) to create the antioxidant solution.

The specimens were immersed and irrigated with antioxidant solutions for 10 minutes at a flow rate of $1 \mathrm{~mL} / \mathrm{min}$. After the antioxidant treatment was performed, the specimens were washed with distilled water for 30 seconds.

\subsection{Restorative procedures}

The NB group was restored 7 days after immersion in artificial saliva solution at $37^{\circ} \mathrm{C}$. The BR7 group was restored after bleaching and immersion in artificial saliva for 7 days. All the other groups were restored immediately after bleaching (B group) and application of antioxidant agents (BSA, BMC and BPC groups).

All specimens were etched with $35 \%$ phosphoric acid (Scotchbond Etchant, 3M Dental Products, St. Paul, MN, USA) for 30 seconds, washed and blot-dried. An ethanol- and water-based adhesive (Adper Single Bond Plus, 3M ESPE, St. Paul, MN, USA) was then applied for 15 seconds and light cured for 10 seconds, according to manufacturer's instructions. For each specimen, a composite buildup (Filtek Z350, 3M ESPE, St. Paul, MN, USA) was made with a Teflon matrix and each $2 \mathrm{~mm}$ increment was light-cured for 20 seconds (Curing Light XL 3000; 3M ESPE/ St. Paul, MN, USA). The restored specimens were stored in artificial saliva at $37^{\circ} \mathrm{C}$ for 24 hours and thermocycled for 5000 cycles at $5{ }^{\circ} \mathrm{C}$ and $55^{\circ} \mathrm{C}$ with 30 seconds dwell time ${ }^{17}$.

\subsection{Microtensile bond strengths}

All specimens were sectioned parallel to the adhesive interface to obtain slabs with a thickness of $0.8 \pm 0.2 \mathrm{~mm}$. Each slab was attached to a phenolic ring and a second set of sections of $0.8 \pm 0.2 \mathrm{~mm}$ thick, were obtained perpendicular to the adhesive interface. Specimens were tested individually by attaching them to a microtensile jig using cyanoacrylate glue (Zapit; Dental Ventures of America, Inc, Corona, CA). The sticks were then subjected to a microtensile load test using a universal testing machine (DL-1000, EMIC, São José dos Pinhais, PR, Brazil) with $10 \mathrm{~kg}$ load cell at $1 \mathrm{~mm} / \mathrm{min}$ crosshead speed. An absolute digital caliper (Mitutoyo Corp, Kanogawa, Japan) with an accuracy of $0.001 \mathrm{~mm}$ was used to measure the sides of the bonding interface and calculate the bonding area in $\mathrm{mm}^{2}$. The microtensile bond strengths were obtained in MPa.

The failures were observed with a stereoscopic loupe (Zeiss: West Germany - type 475200/9901, 10x) and classified as adhesive (A), cohesive enamel (CE), cohesive resin (CR) or mixed (M).

The data were tested using a 1-way ANOVA statistical analysis and Tukey test, at a 5\% significance level.

\section{Results}

There was a statically significant difference among the experimental groups $(\mathrm{p}=0.0000)$. According to the Tukey test, the highest bond strength values were found with the NB and BSA groups. Groups B and BMC demonstrated the lowest bond strength values, statically different from the BR7 and BPC groups (Table 2).

The adhesive failure was found to be prevalent ( 83 to 100\%) in all groups tested (Table 3).

\section{Discussion}

The microtensile test is effective for analysis of the bond strength of restorative materials and tooth structure. One of the main advantages of this test is the possibility of determining the location of the fracture, obtaining several specimens of a single material, and evaluation of bond strength in small areas.

The reduced bond strength of composite resin to bleached enamel may be caused by multifactorial events ${ }^{18-20}$. The bleaching reaction promotes the release of oxygen which decreases the bond strength. The enamel acts as a reservoir for residual oxygen, which makes difficult its release immediately after bleaching. Therefore, morphological changes such as the increase of porosity and loss of prismatic form are observed in the bleached enamel ${ }^{21-23}$. The mineral content of enamel is reduced and resin tags observed are less defined and fragmented ${ }^{24}$. 
Table 2. Mean bond strength values $(\mathrm{MPa})$ and standard deviation of the experimental groups (Means followed by different capital letter in column are significantly different).

\begin{tabular}{cccc}
\hline Groups & $\begin{array}{c}\text { Mean } \\
(\mathrm{MPa})\end{array}$ & $\begin{array}{c}\text { Standard } \\
\text { deviation }\end{array}$ & $\begin{array}{c}\text { Homogeneous } \\
\text { groups }\end{array}$ \\
\hline NB & 30.95 & 11.97 & $\mathrm{~A}$ \\
B & 14.10 & 4.45 & $\mathrm{C}$ \\
BR7 & 21.41 & 6.12 & $\mathrm{~B}$ \\
BSA & 30.34 & 8.73 & $\mathrm{~A}$ \\
BMC & 13.25 & 6.02 & $\mathrm{C}$ \\
BPC & 22.81 & 6.00 & $\mathrm{~B}$ \\
\hline
\end{tabular}

Table 3. Distribution of types of the failures for each experimental group.

\begin{tabular}{ccccc}
\hline Groups & CR & CE & A & M \\
\hline NB & 0 & 2 & 16 & 0 \\
B & 0 & 0 & 18 & 0 \\
BR7 & 0 & 0 & 16 & 2 \\
BSA & 0 & 2 & 15 & 1 \\
BMC & 0 & 0 & 18 & 0 \\
BPC & 0 & 0 & 16 & 2 \\
\hline
\end{tabular}

The application of antioxidant agents after bleaching has been recommended as a way to reduce the waiting period between bleaching and restorative procedures by eliminating the reactive oxygen from the dental substrate $e^{1-3,10,17}$. Some anthocyanins of the flavonoids class such as malvidin and pelargonidin are present in fruits and vegetables, and have high antioxidant properties ${ }^{13}$. The malvidin is a non-enzymatic agent present in the cherries, strawberries, red grapes, teas, and fruits with dark pigments. The pelargonidin has also antioxidant properties and it is found present in radishes, strawberries, tamarinds, and flowers (geraniums and dark grape skins) ${ }^{25}$. However, the effect of these antioxidant agents on bond strength of bleached enamel is unknown.

The null hypothesis of this study was rejected because it was found that different antioxidant agents affect the bond strength of enamel immediately after bleaching. Other research ${ }^{1,17,25,26}$ studies have found that the $10 \%$ sodium ascorbate in fact reverted the reduced bond strength to bleached enamel. The application of this antioxidant agent for 10 minutes promoted higher bond strength than the immersion of the enamel in artificial saliva for 1 week. Therefore, the sodium ascorbate may be an alternative to delayed bonding, since it promotes the complete reversal of bond strength immediately after bleaching. Ascorbic acid and its sodium salt are antioxidants with the capacity to reduce oxidative compounds, especially free radicals. Sodium ascorbate allows free-radical polymerization of the adhesive resin to proceed without premature termination. This is made possible by restoring the altered redox potential of the oxidized bonding substrate thus reversing the compromised bonding ${ }^{26}$.

The use of pelargonidin after bleaching increased the bond strength to enamel. The same result was obtained with a delaying bonding for 1 week. According to Volp et al. ${ }^{27}$, flavonoid antioxidants, such as pelargonidin that have a higher number of hydroxyl groups in the positions 4, 5 and 6 have been found to have higher antioxidant effectiveness. In this study, it was observed that pelargonidin does in fact have an antioxidant effect but it was not able to completely reverse the reduced bond strength of composite to bleached enamel as the same as it has been observed with unbleached enamel.
The malvidin antioxidant agent did not restore the reduced bond strength of composite resin to bleached enamel. Additionally, the application of malvidin resulted in statistically lower bond strength than the pelargonidin chloride, but it was similar to bleached enamel. Although, malvidin has hydroxylation in compound rings with one $\mathrm{OH}$-group in the $\mathrm{B}$ ring $\left(4^{\prime}-\mathrm{OH}\right)^{27}$, this antioxidant agent was not able to eliminate the reactive oxygen present in the dental substrate after bleaching.

In this study, we observed that $10 \%$ sodium ascorbate is an effective antioxidant agent, because it can totally reverse the bond strength to enamel after bleaching. The pelargonidin antioxidant agent should be used with precaution, since it promotes lower bond strength than that of unbleached enamel. The malvidin antioxidant agent has not been proven to reverse the bond strength of composite to enamel after the bleaching procedure. However, the concentration of $200 \mu \mathrm{m} / \mathrm{mL}$ to the pelagornidin and malvidin agents, was the same used by Zhang et al. ${ }^{16}$, who reported tumor cell proliferation inhibitory activity by pelagornidin and malvidin anthocyanidins at this level of concentration. Further evaluation of malvidin and pelargonidin at different concentration levels is necessary for the purpose of reversing the reduction in bond strength of composite to bleached enamel.

Therefore, further research should be conducted to observe the antioxidant capacity of flavonoids on the dental substrate immediately after the bleaching procedure.

\section{Conclusions}

1. Bleaching with $38 \%$ hydrogen peroxide reduced the bond strength of composite to enamel.

2. The application of pelargonidin and delaying bonding for 1 week after bleaching increased the bond strength to bleached enamel.

3. Sodium ascorbate was the only antioxidant agent able to reverse the bond strength to enamel immediately after bleaching.

\section{Acknowledgement}

The authors would like to thank FAPESP (grant \#08/58058-6) for the financial support.

\section{References}

1. Bulut H, Turkun M and Kaya AD. Effect of an antioxidizing agent on the shear bond strength of brackets bonded to bleached human enamel. American Journal of Orthodontics and Dentofacial Orthopedics. 2006; 129(2):266-272. PMid:16473720. -doi:10.1016/j.ajodo.2004.03.043

2. Lai SC, Tay FR, Cheung GS, Mak YF, Carvalho RM, Wei SH et al. Reversal of compromised bonding in bleached enamel. Journal of Dental Research. 2002; 81(7):477-481. PMid:12161460. doi:10.1177/154405910208100709

3. Dishman MV, Covey DA and Baughan LW. The effects of peroxide bleaching on composite to enamel bond strength. Dental Materials. 1994; 10(1):33-36. doi:10.1016/0109-5641(94)90019-1

4. Cavalli V, Reis AF, Gianini M and Ambrosano GM. The effect of elapsed time following bleaching on enamel bond strength of resin composite. Operative Dentistry. 2001; 26(6):597-602. PMid:11699184.

5. Lai SC, Mak YF, Cheung GS, Osorio R, Toledano M, Carvalho RM et al. Reversal of compromised bonding to oxidized etched dentin. Journal of Dental Research. 2001; 80(10):1919-1924. PMid:11706952. doi:10.11 77/00220345010800101101

6. Cvitko E, Denehy GE, Swift EJ Jr and Pires JA. Bond strength of composite resin to enamel bleached with carbamide peroxide. Journal of Esthetic Dentistry. 1991; 3(3):100-102. doi:10.1111/j.1708-8240.1991. tb00976.x 
7. Barghi N and Godwin JM. Reducing the adverse effect of bleaching on composite-enamel bond. Journal of Esthetic Dentistry. 1994; 6(4):157-161. doi:10.1111/j.1708-8240.1994.tb00852.x

8. Kalili T, Caputo AA, Mito R, Sperbeck G and Matyas J. In vitro toothbrush abrasion and bond strength of bleached enamel. Practical Periodontics and Aesthetic Dentistry. 1991; 3(5):22-24. PMid:1813038.

9. Sung EC, Chan M, Mito R and Caputo AA. Effect of carbamide peroxide bleaching on the shear bond strength of composite to dental bonding agent enhanced enamel. Journal of Prosthetic Dentistry. 1999; 82(5):595-598. doi:10.1016/S0022-3913(99)70060-0

10. Turkun M and Kaya AD. Effect of $10 \%$ sodium ascorbate on the shear bond strength of composite resin to bleached bovine enamel. Journal of Oral Rehabilitation. 2004; 31(12):1184-1191. PMid:15544654. doi:10.1111/j.1365-2842.2004.01369.x

11. Comlekoglu ME, Gokce B, Kaya AD, Turkun M and Ozpinar B. Reversal of reduced bond strength after bleaching. General Dentistry. 2010; 58(3):258-263. PMid:20478806.

12. Swift EJ Jr. Restorative considerations with vital tooth bleaching. Journal of the American Dental Association. 1997; 128:60S-64S. PMid:9120150.

13. Hassimotto NMA, Genovese MI and Lajolo FM. Antioxidant activity of dietary fruits, vegetables, and commercial frozen fruit pulps. Journal of Agricultural and Food Chemistry. 2005; 53(8):2928-2935. PMid:15826041. doi:10.1021/jf047894h

14. Sasaki RT, Flório FM and Basting RT. Effect of $10 \%$ sodium ascorbate and $10 \%$ alpha-tocopherol in different formulations on the shear bond strength of enamel and dentin submitted to a home-use bleaching treatment. Operative Dentistry. 2009; 34(6):746-752. PMid:19953786. doi:10.2341/09-029-L

15. Rose RC and Bode AM. Biology of free radical scavengers: an evaluation of ascorbate. FASEB Journal. 1993; 7(12):1135-1142. PMid:8375611.

16. Zhang Y, Vareed S K and Nair MG. Human tumor cell growth inhibition by nontoxic anthocyanidins, the pigments in fruits and vegetables. Life Sciences. 2005; 76(13):1465-1472. PMid:15680311. doi:10.1016/j. lfs.2004.08.025

17. Bulut H, Kaya AD and Turkun M. Tensile bond strength of brackets after antioxidant treatment on bleached teeth. European Journal of
Orthodontics. 2005; 27(5):466-471. PMid:16043470. doi:10.1093/ejo/ cji044

18. Spyrides GM, Perdigão J, Pagani C, Araujo MA and Spyrides SM. Effect of whitening agents on dentin bonding. Journal of Esthetic Dentistry. 2000; 12(5):264-270. doi:10.1111/j.1708-8240.2000.tb00233.x

19. Demarco FF, Turbino ML, Jorge AG and Matson E. Influence of bleaching on dentin bond strength. American Journal of Dentistry. 1998; 11(2):78-82. PMid:8730271. doi:10.1111/j.1365-2842.1996.tb00848.x

20. Josey AL, Meyers IA, Romaniuk K and Symons AL. The effect of a vital bleaching technique on enamel surface morphology and thebonding of composite resin to enamel. Journal of Oral Rehabilitation. 1996; 23(4):244-250. PMid:8730271. doi:10.1111/j.1365-2842.1996.tb00848.x

21. Cavalli V, Gianinni M and Carvalho RM. Effect of carbamide peroxide bleaching agents on tensile strength of human enamel. Dental Material. 2004; 20(8):733-739. PMid:15302454. doi:10.1016/j.dental.2003.10.007

22. Kaya $\mathrm{AD}$ and Türkün M. Reversal of dentin bonding to bleached teeth. Operative Dentistry. 2003; 28(6):825-829. PMid:14653300.

23. Sattabanasuk V, Viracha V, Qian F and Armstrong SR. Resin-dentin bond strength as related to different surface preparation methods. Journal of Dentistry. 2007; 35(6):467-475. PMid:17331635. doi:10.1016/j. jdent.2007.01.002

24. Perdigão J, Francci C, Swift EJ Jr, Ambrose WW and Lopes M. Ultramorphological study of the interaction of dental adhesives with carbamide peroxide-bleached enamel. American Journal of Dentistry. 1998; 11(6):291-301.

25. Türkün M, Celik EU, Kaya AD and Arici M. Can the hydrogel form of sodium ascorbate be used to reverse compromised bond strength after bleaching? Journal of Adhesive Dentistry. 2009; 11(1):35-40.

26. Gökçe B, Cömleko lu ME, Ozpinar B, Türkün M and Kaya AD. Effect of antioxidant treatment on bond strength of a luting resin to bleached enamel. Journal of Dentistry. 2008; 36(10):780-785. doi:10.1016/j. jdent.2008.05.008

27. Volp ACP, Renhe IRT, Barra K and Stringueta PC. Flavonoids Anthocyanins: characteristics and properties in nutrition and health. Revista Brasileira de Nutrição Clínica. 2008; 23(2):141-149. 